\title{
Villous adenoma of the ampulla of Vater
}

\author{
A.K. Malik, M.K. Baruah, N. Pravin and R.N. Kataria \\ Department of Gastroenterology, Pathology and Surgery, Postgraduate Institute of Medical Education \& \\ Research, Chandigarh-160012, India
}

Summary: A case of villous adenoma of the ampulla of Vater in a 40 year old male is described. The clinical significance of this rare tumour is discussed and the relevant literature reviewed.

\section{Introduction}

Villous tumours of the duodenum are rare neoplasms of the upper gastrointestinal tract. (Everett et al., 1981). Three cases only have been reported arising specifically from the ampulla of Vater, all with invasive carcinoma (Meltzer et al., 1966; Dayal et al., 1972). Frank malignancy in all villous tumours of the duodenum is found in $21 \%$ of cases (Neuman et al., 1984). Our recent observation of a case of villous adenoma of the ampulla prompted us to review relevant publications.

\section{Case report}

A 40 year old male was admitted in March, 1984 with complaints of progressive jaundice, intense pruritus and weight loss for 3 months. There was no history of abdominal pain, bleeding or fever. A smooth, nontender liver, $5 \mathrm{~cm}$ below the right costal margin and a tense gall bladder were felt. Serum bilirubin was $103 \mu \mathrm{mol} / \mathrm{l}$. An ultrasound scan showed markedly dilated intrahepatic biliary radicals, gall bladder and common bile duct. The pancreatic head was normal. On endoscopy a polypoidal growth without ulceration was found around the papilla. At operation, a soft polypoidal mass, $3 \mathrm{~cm}$ in diameter was found overlying the ampulla. Frozen section from the mass did not show malignant change. Transduodenal polypectomy and sphincteroplasty was carried out. The specimen grossly measured $3 \times 2 \times 1.75 \mathrm{~cm}$ with fine papillary fronds on the outer surface (Figure 1). On microscopic examination, typical features of a benign tubulovillous adenoma were present. The stalk was free of tumour and features of in situ carcinoma were absent.

At follow-up after 6 months, the patient had gained

Correspondence: A.K. Malik, M.D., Department of Gastroenterology, P.G.I.M.E.R., Chandigarh-160012, India. Accepted: 30 May 1985

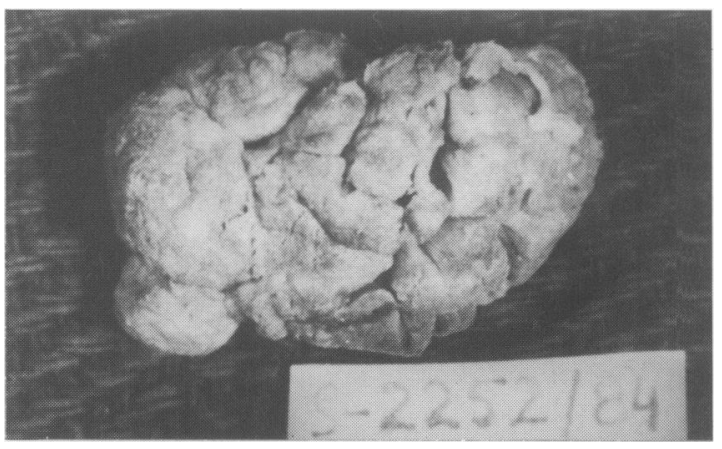

Figure 1 Macrograph of the polypoidal growth showing velvety surface.

weight, jaundice had disappeared and endoscopy showed no recurrence.

\section{Discussion}

Although villous tumours of the colon and rectum are not uncommon, those of the small intestine are very rare. Villous tumour of the duodenum was first documented as a case report by Golden (1928). Since then sporadic case reports have appeared; to date there are 53 published cases (Mir-Madjlessi et al., 1973; Kutin et al., 1975; Schulten et al., 1976; Everett et al., 1981; Neuman et al., 1984).

Diagnostic difficulty arises because of the ill-defined nature of the presenting symptoms. Neuman et al. (1984) have suggested that $27 \%$ of patients present with a gastrointestinal bleed, $24 \%$ with gastric outlet obstruction, $19 \%$ with vague upper abdominal pain and $24 \%$ with obstructive jaundice. The latter is due to the stricture and location of the tumour which can cause obstruction at the ampulla. It is also interesting to note that $90 \%$ of such patients with jaundice show 
Table I Villous tumours of the ampulla of Vater

\begin{tabular}{|c|c|c|c|c|c|}
\hline Authors & $\begin{array}{l}\text { Age } \\
\text { and sex }\end{array}$ & $\begin{array}{l}\text { Presenting } \\
\text { features }\end{array}$ & $\begin{array}{l}\text { Preoperative } \\
\text { diagnosis }\end{array}$ & Pathology & Treatment \\
\hline Meltzer et al., 1966 & $69 \mathrm{M}$ & $\begin{array}{c}\text { Vomiting, weight } \\
\text { loss, jaundice }\end{array}$ & X-ray filling defect & $\begin{array}{l}\text { Papillary tumour } \\
\text { extending into } \\
\text { wall of duodenum } \\
\text { Invasive }\end{array}$ & $\begin{array}{l}\text { Whipple's } \\
\text { operation }\end{array}$ \\
\hline Meltzer et al., 1966 & $60 \mathrm{M}$ & $\begin{array}{c}\text { Weakness, anorexia, } \\
\text { jaundice }\end{array}$ & $\begin{array}{l}\text { Filling defect with } \\
\text { mucosal distortion, } \\
\text { Cholangiogram } \\
\text { showed ampullary } \\
\text { obstruction }\end{array}$ & $\begin{array}{l}\text { Papillary tumour } \\
\text { occluding common } \\
\text { bile duct } \\
\text { Invasive }\end{array}$ & Excision \\
\hline Dayal et al., 1972 & $56 \mathrm{~F}$ & $\begin{array}{l}\text { Epigastric pain } \\
\text { weight loss } \\
\text { No jaundice }\end{array}$ & $\begin{array}{l}\text { Filling defect } \\
\text { with spiculations } \\
\text { (Soap-bubble) }\end{array}$ & $\begin{array}{c}\text { Sessile polyp } \\
5 \times 2.7 \times 1.7 \mathrm{~cm} \\
\text { Invasive }\end{array}$ & $\begin{array}{l}\text { Whipple's } \\
\text { operation }\end{array}$ \\
\hline Present case & $40 \mathrm{M}$ & Jaundice, weight loss & $\begin{array}{l}\text { Endoscopy showed } \\
\text { polypoid growth }\end{array}$ & $\begin{array}{c}\text { Sessile polyp } \\
3 . \times 2 . \times 1.75 \mathrm{~cm} \\
\text { Benign }\end{array}$ & Excision \\
\hline
\end{tabular}

evidence of malignancy at histopathology (Neuman et al., 1984). Endoscopic methods have improved diagnostic accuracy. Gastroduodenoscopy will demonstrate about $90 \%$ of the lesions, the rest consisting of tumours in the fourth part of the duodenum. The characteristic 'soap-bubble' appearance on X-ray of the stomach and duodenum has been referred to by various authors (Meltzer et al., 1966; Bremer et al., 1968; Everett et al., 1981) but is not an invariable finding.

The pathology of villous adenomas of the duodenum is similar to those of the colon. Slender fibro-vascular cores are lined by a neoplastic epithelium. Since malignant potential is high, multiple sections including from the stalk need to be taken to exclude focal occult carcinoma.

Villous tumours of the ampulla are extremely rare. Three previous cases (Table I) showed evidence of malignancy on microscopic examination. Obstructive

\section{References}

BREMER, E.H., BATTAILE, W.G. \& BULLE, P.H. (1968). Villous tumours of the upper gastrointestinal tract. American Journal of Gastroenterology, 50, 135.

DAYAL, Y., BASS, A.G., KRAFT, A.R., GLOTZER, D.J. \& GOLDMAN, H. (1972). Villous adenoma of the duodenum. American Journal of Surgery, 124, 394.

EVERETT, G.D., SHIRAZI, S.S. \& MITROS, F.A. (1981). Villous tumours of the duodenum. American Journal of Gastroenterology, 75, 376.

GOLDEN, R. (1928). Non-malignant tumours of the duodenum. American Journal of Roentgenology, Radium Therapy and Nuclear Medicine, 20, 405.

KUTIN, N.D., RANSON, J.H.C., GOUGE, T.H. \& LOCALIO, jaundice due to the tumour is invariable. However, the case reported by Dayal et al., (1972) did not have jaundice, though a drip infusion cholangiogram at the second admission of the patient showed a block at the distal end of the common bile duct. In the case reported here, obstructive jaundice was the presenting feature. Simple polypectomy and sphincteroplasty was done as the frozen section did not show features of malignancy. In frank malignant lesions radical surger $f$ such as pancreatico-duodenectomy is the treatment of choice.

\section{Acknowledgements}

The authors thank Dr J.B. Dilawari for performing the ERCP. Thanks are also due to Mr Ram Pal for secretarial help and Mr Y.P. Kohli for the illustration.

S.A. (1975). Villous tumours of the duodenum. Annals of Surgery, 181, 164.

MELTZER, A.D., OSTRUM, B.J. \& ISARD, J.J. (1966). Villous tumours of stomach and duodenum. Radiology, 87, 511. MIR-MADJLESSI, S.-H., FARMER, R.G. \& HAWK, W.A (1973). Villous tumours of the duodenum and jejunum. American Journal of Digestive Diseases, 18, 467.

NEUMAN, D.H., DOERHOFF, C.R. \& BUNT, T.J. (1984). Villous adenoma of the duodenum. American Surgeon, 50, 26.

SCHULTEN, M.R., OYASU, R. \& BEAL, J.M. (1976). Villous adenoma of the duodenum and review of the literature. American Journal of Surgery, 132, 90. 